\title{
Re-imagining rural cooperation in Atlantic Canada
}

\author{
Greg Cameron a,b* \\ Dalhousie University \\ Louise Hanavan ${ }^{b, c}$ \\ Mount Saint Vincent University
}

Submitted August 20, 2013 / Revised January 6, 2014 / Accepted January 29, 2014 /

Published online June 3, 2014

Citation: Cameron, G., \& Hanavan, L. (2014). Re-imagining rural cooperation in Atlantic

Canada. Journal of Agriculture, Food Systems, and Community Development, 4(3), 29-45.

http://dx.doi.org/10.5304/jafscd.2014.043.008

Copyright (C) 2014 by New Leaf Associates, Inc.

\begin{abstract}
As they struggle to be competitive in a global market economy, agricultural cooperatives in Atlantic Canada appear to be in overall decline, shrinking in both numbers and members. This strategic policy analysis looks at what new role the remaining agricultural cooperatives might play in a more regionalized marketplace. Using a mixed methods approach we gathered secondary data and interviewed key leaders and managers in the agricultural cooperative community in Atlantic

${ }^{\text {a }}$ Department of Business and Social Sciences, Faculty of Agriculture, Dalhousie University.

b Rural Research Centre, Faculty of Agriculture, Dalhousie University.

${ }^{c}$ Department of Applied Human Nutrition, Mount Saint Vincent University; Louise.Hanavan@msvu.ca

* Corresponding author: Greg Cameron, Rural Research Centre, Faculty of Agriculture, Dalhousie University; 56-58 Rock Garden Road, P.O. Box 550; Truro, Nova Scotia B2N 5E3 Canada; Gregory.Cameron@dal.ca
\end{abstract}

Canada. Results suggest that while progress is being made to decommodify and develop new value-added products and regionally oriented supply chains, a transition to a more sustainable regional economic cooperative model is elusive and not likely to come about without a more localized rural cooperative system uniting all agricultural cooperatives, together with greater unity between the provincial cooperative councils.

\section{Keywords}

agricultural cooperatives, cooperative councils, marketing cooperatives, supply cooperatives, service cooperatives, production cooperatives, traditional and new cooperatives, Atlantic Canada

\section{Introduction}

Speakers at Quebec City's 2012 marquee cooperative summit, celebrating the UN's International Year of the Co-operative, widely critiqued the conventional market-driven economic model intrinsic to the West, and instead called for a new sustain- 
able economic paradigm (Novkovic, 2012). This call for economic sustainability aptly applies to the rural world of Organisation for Economic Cooperation and Development (OECD) countries where family farms and domestic food systems are increasingly exposed to the vagaries of the global economy. Canada, an OECD country, is no exception, caught as it is in the paradox of being an agricultural superpower while losing its family-farm sector.

Canada's rural regions (officially defined as being areas with fewer than 1,000 inhabitants and a population density below 400 people per square kilometer (1,041 per square mile), and in which 6.3 million Canadians live, making up 18.9 percent of the national population) (Statistics Canada, 2012a) are undergoing dramatic changes, including low rates of business creation; boom-bust natural resource cycles; out-migration; loss of agricultural land; fewer and more capital-intensive farms; the decline of domestic food production; growing concentration and consolidation in supply, processing, and food retail distribution networks; depressed farm product prices induced by global commodity pricing and trade issues; consumer demand for the cheapest food regardless of its origin or cost or conditions of production; chronic under- and unemployment nationally; government fiscal deficits; and the increasing competitiveness of the emergent economies of the "Global South" (Canadian Cooperative Association [CCA], 2011; Nova Scotia Federation of Agriculture, n.d.; Scott \& Colman, 2008; Senate Committee on Agriculture and Forestry, 2006; Senate Committee on Agriculture and Forestry, 2008; United Nations Department of Economic and Social Affairs, 2013).

As a concurrently shared power in the Canadian federal system, the current federal/provincial agriculture policy for 2013 to 2018, "Growing Forward 2" (henceforth referred to as GF2) built on a legacy of similar agricultural policy frameworks - focuses on competition, innovation, export markets, and free trade (Agriculture and Agri-Food Canada, n.d.). This indicates a shift in policy away from state-supported agriculture to one based on neoliberal market principles. In cooperative leadership circles there is growing disquiet over the potential implications of GF2 for agricultural cooperatives (Canadian Co-operative Association [CCA], 2011). In earlier times the core principles of the world cooperative movement voluntary and open membership, democratic member control, member economic participation, autonomy and independence, continual education, cooperation among cooperatives, and concern for community (International Co-operative Alliance [ICA], 2013) - paid real dividends in the tight and vibrant rural communities of $20^{\text {th }}$ century Canada (MacPherson, 1979). Today, however, is a different era. Agricultural cooperatives face the loss of farmland, stable memberships, and critical rural infrastructure like railways, marketing centers, food retail outlets, tractor dealerships, processing plants, and institutional price supports for domestic food production (CCA, 2011).

These trends apply to all of Canada's regions and provinces including Atlantic Canada, where the authors are based. Atlantic Canada comprises the four provinces of Nova Scotia, New Brunswick, Prince Edward Island, and Newfoundland and Labrador, and is home to approximately 2.3 million people. Less industrialized than central and western Canada, the region has traditionally been dependent on industries such as coal, steel, and shipbuilding, and on resource sectors including fishery and forestry. In recent years, regional economic policy has shifted to new knowledge sectors (e.g., call centers) and "gateway" initiatives into the global economy (Fredericton Daily Gleaner, 2005; Johnson, Hodgett, \& Royle, 2007). Atlantic Canada's agriculture varies by province but is generally characterized by mixed farming such as dairy, beef, potatoes, and blueberries. Regionally speaking, there are fewer farms in Atlantic Canada than elsewhere in Canada (Canadian Geographic, n.d.; Statistics Canada, 2012b).

Although Atlantic Canada has a storied cooperative tradition, the extent to which these wider trends in agriculture have affected Atlantic Canada's agricultural cooperatives (both the traditional cooperatives emanating from $20^{\text {th }}$ century social movements, and the more recent grassroots local food cooperatives) is not clear. The crucial issue we wished to explore in this study is the views of the Atlantic Canadian cooperative community on the economic and policy trends facing 
contemporary agricultural cooperatives and the possibilities for a more sustainable rural cooperative architecture.

\section{Objectives and Methodology}

This research had two related objectives:

1. To seek the evaluation of the Atlantic Cooperative Councils on whether agricultural cooperatives could affect food security (reviving domestic food production) at the local and regional levels as a measure of their resilience; and

2. To identify political, social, and economic challenges and opportunities for the success of local-scale agricultural cooperatives in Atlantic Canada.

This interviewed-based case study employed semistructured phone interviews conducted in April and May 2011 with a cooperative council representative in each Atlantic province: The Nova Scotia (NS) Co-operative Council, the Newfoundland and Labrador (Nfld. \& Lab.) Federation of Co-operatives, the Prince Edward Island (PEI) Cooperative Council, and the Co-operative Enterprise Council of New Brunswick (NB). We contacted representatives in senior leadership positions from each of the provincial cooperative councils. (See the interview guide in the appendix.) Due to differences in organizational structures among the councils, some interviewees were staff directors, and some were volunteer board directors. All were able to speak from experience about specific cooperatives as well as about wider policy trends in their respective provincial cooperative sector. Two interviews were also conducted with federal and provincial government farm loan specialists. We also attended cooperative public events and accessed the "grey" policy literature that is listed in the reference section.

This research builds on the findings of targeted consultations, known as "Foundations Sessions," that were conducted by the Rural Research Centre, Dalhousie University, in every province between 2008 and 2011 with government, industry, and civil society representatives connected to agriculture and rural development in Atlantic Canada. A total of six Foundation Sessions were held, generally with six in attendance per session. The Foundation Sessions frame some of the context to this paper and, in certain instances, offer direct insights on the region's cooperatives.

The paper is organized as follows. Part 1 has set the policy context framing the agricultural cooperatives, together with the methodology of the paper. Part 2 addresses the concerns and recommendations of the cooperative community toward federal and provincial agricultural policy, followed by a national and regional overview of the agricultural cooperatives. Parts 3 through 6 break down the agricultural cooperatives into their marketing, supply, service, and production subsectors. The interview results are generally organized according to the opportunities and constraints facing each subsector in light of the GF2 policy context, while delineating their differing trajectories. Part 7 calls for a more localized rural cooperative model uniting all of its segments, and backed by an interprovincial co-operative council agricultural entity.

\section{National and Regional Overview of Cooperative Policy and Agricultural Cooperatives}

\section{Cooperative Views of Federal and Provincial Agricultural Policy}

The CCA secretariat, cooperative specialists, Atlantic Co-operative Council representatives, regional roundtables, and Foundation Sessions all unanimously called for agricultural policy to support a diversity of farm sizes and production approaches that focus on domestic markets, appropriate regulations, adequate provincial funding, tax breaks, research, and technical support. Also urged was a greater diversity of partnerships with regional organizations, local municipalities, economic development organizations, food security and community groups, and cooperatives.

However, the commitments of the provincial and federal governments to the long-term growth of a strong agricultural cooperative movement are at best unsteady. While our research did identify some positive examples of collaboration with provincial departments (e.g., the Department of Innovation, Business and Rural Development of 
Nfld.\& Lab. stands out), Atlantic provincial governments, by and large, continue to embrace large-scale natural resource projects, or capital projects (e.g., "fracking" and governmentprocured ship-building), or commodity agriculture (provincial agricultural departments received few accolades here), as the primary drivers of provincial economic growth rather than community economic development. Cooperative affairs are invariably lodged in less than prominent departments (e.g., Service Nova Scotia and Municipal Relations) and there is a lack of awareness about cooperatives among government staff in other departments (e.g., economic development, regional development) and the wider public in general. At the federal level, austerity measures implemented since 2008 - staff cuts, the shuffling of the federal secretariat, and the discontinuation of the Co-operative Development Initiative in 2012 (Canadian Worker Co-op Federation, n.d.) - are indicative of the low priority of the cooperative file in the national capital, Ottawa.

Below we provide an overview of the national and regional agricultural cooperatives before turning to a more detailed look at the implications of this emerging policy environment for Atlantic Canada's agricultural subsectors.

\section{National and Regional Overview of Agricultural Cooperatives}

Agricultural cooperatives have been a major component of the Canadian cooperative movement since the $19^{\text {th }}$ century. Today, as a result of this legacy, agricultural cooperatives (generally a pro-

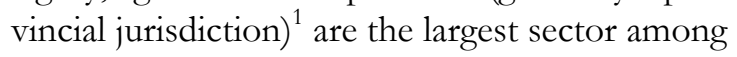

${ }^{1}$ A cooperative wishing to incorporate under the federal legislation must have its business in two or more provinces nonfinancial cooperatives in Canada, representing a greater share of employees (37.4 percent of the total) and a larger share of revenues (46.1 percent) than any other cooperative sector (CCA, 2011). Of the 5,679 nonfinancial cooperatives in Canada, there are 1,309 agricultural cooperatives. In 2007, agricultural cooperatives had over CA $\$ 8.9$ billion in sales, across a range of different sectors. Canada's cooperative "powerhouse" is the French-speaking province of Quebec. The total revenue of its 231 agricultural cooperatives was over CA $\$ 8.3$ billion in 2007, which is 81.9 percent of Quebec's total cooperative revenues (personal communication from Rural and Co-operative Secretariat, 2007).

Atlantic Canada's cooperative sectors are smaller compared to those of the rest of the provinces. Within Atlantic Canada, Nova Scotia has the greatest number of registered cooperatives, while New Brunswick has the largest number of members, greatest asset base (as percentage of population), and most employees. PEI's strong agricultural base is reflected in the revenues of its agricultural cooperatives, which accounted for CA $\$ 143$ million (61 percent) of total cooperative revenues (personal communication from Rural and Cooperative Secretariat, 2007). Newfoundland and Labrador has the smallest cooperative profile

and/or have a fixed place of business in more than one province (Industry Canada, 2013). 
nationally and regionally (see Table 1).

Our schema follows the functional definitions contained in the CCA's excellent document Growing Forward Through Co-operation (2011), which breaks down the agricultural cooperatives into the subsectors of marketing, supply, services, and production. The following sections address the differential impacts of policy on these four main segments of the agricultural cooperatives.

\section{Agricultural Marketing Cooperatives}

\section{Overview}

Agricultural marketing cooperatives market, distribute, process, and add value to the farm products of their members. Numbering 291 in Canada, they encompass diary (32), vegetables (35), fruit (51), fruit and vegetables (4), greenhouse vegetables (9), grains and oilseeds (18), livestock (63), poultry and eggs (11), honey and maple (12), and other marketing types (56) (CCA, 2011). Nationally, agricultural marketing cooperatives have over 39,000 members, with 25,000 employees in total (CCA, 2011). Dairy cooperatives account for almost half of all revenue from Canadian cooperatives, followed by hogs and poultry. Canadian dairy processing cooperatives have a market share of 42 percent of all sales in Canada. The dairy sector is bolstered by Canada's Supply Management (SM) system, introduced in 1970 by the federal government to provide price stability to dairy, eggs, and poultry farmers and processors, and a guaranteed supply of these commodities to consumers. SM has three pillars: the managing of production (quotas), import controls (tariffs and trade barriers), and cost of production pricing. The system normally does not require public subsidies (Dairy Commission of Canada, 2012). The next two sections cover the opportunities and challenges inside of the SM system in Atlantic Canada.

\section{Secure Regional Markets}

In Atlantic Canada, Scotsburn Co-operative Services Ltd. (founded in 1900) ${ }^{2}$ and Farmers Co-

\footnotetext{
${ }^{2}$ Scotsburn recently sold its fluid milk division (two fluid milk processing facilities) and distribution network to the Quebecbased investor-owned business Saputo, which would appear to
}

operative Dairy Ltd. (merged in April 2013 with the Quebec dairy cooperative Agropur, founded in 1938) came in at eighth and tenth of the top ten agricultural cooperatives nationally (CCA, 2011). The dairy cooperatives gradually amalgamated over time, in line with the growing concentration in the farm sector. Scotsburn consists of approximately 94 dairy farmers in Atlantic Canada, while Farmers currently stands at 116 . Seventy-five percent of Nova Scotia's agricultural production is processed in cooperatives, which are critical to value-adding (NS Co-operative Council interview, April 2011). With CA $\$ 243$ million in revenue, Scotsburn accounted for 42 percent of agricultural cooperative revenue in the province. PEI's dairy cooperatives have also thrived (PEI Co-operative Council interview, April 2011). In 2007, for example, Amalgamated Dairies Co-operative Ltd. reported the highest revenue of all PEI cooperatives with CA $\$ 125$ million, which is 87 percent of all agricultural revenues, and 53.4 percent of total cooperative revenue in the province.

The decline in the number of farms, however, also affects dairy farm cooperative numbers, although they are probably producing the same amount of milk. According to one informant, "You can't make a living anymore growing 100 acres of potatoes or milking 20 cows" (PEI Cooperative Council interview, April 2011). Newfoundland and Labrador's dairy cooperatives (Scotsburn, Agropur), based in the provinces of Nova Scotia and Quebec (see table 1), buy milk from Newfoundland-based dairy farmers, numbering around 34, who are not members of those cooperatives (Nfld. \& Lab. Federation of Cooperatives interview, April 2011). SM has also served rural communities in New Brunswick well, as represented by Northumberland Dairy Cooperative, founded in 1942 (Co-operative Enterprise Council of NB interview, April 2011).

indicate further consolidation in the regional dairy industry. Scotsburn will continue its other activities, such as its frozen ice cream and frozen novelties business. Overall, the ownermember profile of the cooperative remains the same including in regards to the purchase of bulk milk by Scotsburn (personal communication with Scotsburn representative, February 7 , 2014). 
Implications of "Free Trade" Agreements

Informants said that many dairy farmers find it hard to believe that SM has not caved in due to lobbying pressure from U.S. dairy interests seeking access to the Canadian market. SM and cooperatives give farmers a chance to set the price (interviewees from Co-operative Enterprise Council of NB, 2011; and NS Co-operative Council, 2011). Our interviewees strongly supported an SM system that appears to be doing well for the moment. For the authors, however, a looming threat became clear when the current conservative government ended the Canadian Wheat Board's monopsony on August 1, 2012, as a result of Bill C-18 (a farmercontrolled single-desk federal grain marketing agency based in Western Canada) in favor of openmarket grain selling (Desmarais \& Wittman, 2014). ${ }^{3}$ Supply Management policy subsequently faced a hostile and synchronized public-relations campaign orchestrated by the corporate media, right-wing think tanks, and Canadian "free trade" ideologues in industry who urged that SM be dismantled, ostensibly to lower prices for consumers (McKenna \& Curry, 2012). The implicit view among some informants was that federal government policies pose a threat to the SM-supported cooperatives.

\section{Innovation Outside of SM}

The story is different for those marketing cooperatives outside SM who must intensify exports, innovate, or create local standards among members, to maintain or gain market share. The formation of a Christmas tree cooperative in Nova Scotia was cited as a good example of export market diversification. It developed a niche market for exporting Christmas trees to Dubai using the container pier in Halifax (the capital of Nova Scotia) (Powell, 2011). By developing common standards among its 40 or so member tree growers, it received higher margins for its trees and was able to take large lucrative contracts (NS Co-operative Council interview, 2011). Another informant cited the example of the Scotian Gold apple marketing cooperative - a Nova Scotia-based cooperative of approximately 30 members with CA $\$ 25$ million in turn-

\footnotetext{
${ }^{3}$ This was preceded by the conventionalization of the major grain marketing cooperatives in western Canada.
}

over. Scotian Gold commercialized its public and private research partnerships through the development of the "Sweetango" apple, which allowed it to get better prices and regular shelf space in the conventional grocery retailers. This was a significant success, since large retailers want a 12 -month supply, not just supplies for part of the year from local farmers, and otherwise ship it in (NS Cooperative Council interview, 2011).

One informant said that farmers should develop export markets with overseas cooperatives to circumvent the large grocery retailers:

[International] partnerships could be taking place within the cooperative model (i.e., cooperatives of cooperatives in NS and Chile, etc.). There is a precedent for this type of activity in "Just Us!" [in Grand Pre, Nova Scotia], which is a worker-owned cooperative of cooperatives with global partners [fair trade coffee]. (NS Co-operative Council interview, 2011)

Other innovations noted were value-added cheese processing by Farmers Dairy Co-operative (now Agropur), a poultry processing cooperative known as ACA, cooperatively marketed blueberries, and the mink cooperatives (NS Co-operative Council interview, 2011).

\section{The Creation of Community Standards}

We asked if government-supported SM should be extended to other commodities, even though this seemed counterintuitive given "free market" trends. Our informants thought this unlikely but felt that perhaps the troubled pork industry would be in favor of it (NS Co-operative Council interview, 2011). This very issue is arising in Newfoundland: "Vegetable producers can't understand why the government can't set up regulatory pricing for vegetables, like for dairy, and the government keeps saying it can't do anything" (Nfld. \& Lab. Federation of Co-operatives interview, 2011). Informants believed expanding SM to other commodities would be attractive to producers, but that Canadian taxpayers would resist funding such a system were it perceived to mean higher food prices. 
Other producers have successfully initiated community-controlled regulatory systems. In Nova Scotia in the early 1980s, the Northumberland Lamb Marketing Co-operative (Brewster Kneen being one of its founders) established a voluntary supply management system, setting prices, controlling quality, negotiating delivery times and volumes with farmers, and supplying the major supermarkets in the province with local lamb year-round:

They are able to pay their producers a premium for off-season lamb and sell it yearround. They basically set local prices. Because it's a smaller market, there is much less imports competition than beef, for example, which is in decline locally. They benefit from efficiencies of scale and constant supply. Northumberland would be considered a small to midsize cooperative. (NS Co-operative Council interview, 2011).

Northumberland faces government regulatory issues, nonetheless, because provincial crossborder meat shipments must be federally inspected. Because Northumberland's abattoir is only provincially inspected, it would have to ship its meat first to PEI, where the nearest federally inspected abattoir is located, if it wished to provide lamb to Co-op Atlantic across the border in New Brunswick (NS Foundation Sessions, 2008).

The overall impression made by the interviews points to the SM marketing cooperatives remaining robust in regional and provincial markets. As for the non-SM marketing cooperatives, some successes have been achieved in export activities and innovation within the GF2 policy framework.

\section{Agricultural Supply Cooperatives}

\section{Overview}

Canada's 235 agricultural supply cooperatives focus on the provision of farm inputs, including fertilizer, chemicals, animal feed, seed, building materials, and petroleum (CCA, 2011). They have 419,000 members across the country, with the highest concentration being in Alberta and Saskatchewan (e.g., Federated Co-operatives), followed by Ontario and Quebec. Supply cooperatives have over 5 million customers, including both farmers and households, with over CA $\$ 14$ billion in sales (CCA, 2011).

\section{Co-op Atlantic a Robust Secondary Entity}

In Atlantic Canada and parts of Quebec (the Magdalen Islands), Co-op Atlantic is the main player for agricultural supply cooperatives. Founded in 1927 as the Maritime Livestock Board, and headquartered in Moncton, New Brunswick, Co-op Atlantic is a second-tier cooperative wholesaler of consumer goods, feed, petroleum, and farm inputs, and is owned by over 100 stores (Brown, 1995; NS Co-operative Council interview, 2011). Co-op Atlantic is the largest retail cooperative in New Brunswick and an example of a large cooperative that grew out of the agricultural sector. It is one of the investors in the Atlantic Beef Producers' Co-operative on PEI (Co-operative Enterprise Council of NB interview, 2011), demonstrating robust interprovincial cooperative linkages.

\section{Farm Supply Cooperatives Are Vulnerable}

Cooperative farm and household retail stores, however, are in precarious business positions. In the words of one informant:

They can have hundreds of thousands of dollars of their business tied up in eight or 10 people due to aging and stagnant memberships. It makes it shaky, then, for a farm store that has its business so concentrated....It boils down to selling the cooperative message - telling farmers why it is important to buy from yourself: You have to find a balance between running it well and seeing that prices are good...but after 20 years or so, you're thinking, it would be really nice at the end of the year to receive a patronage dividend. They've got to be properly run. (PEI Co-operative Council interview, 2011)

Similarly, in Nfld. \& Lab. 60 years ago, there were a lot more agricultural supply cooperatives, but they have been shutting down: "There used to be little cooperative stores that sold farm supplies in every little community. Now farmers tend to phone bigger dealers who are often able to offer better prices" (Nfld. \& Lab. Federation of Co-operatives 
interview, 2011). Agricultural inputs are increasingly produced outside the region, adding to the cost of production. This especially affects younger farmers, who find themselves caught between producing for local markets with inadequate infrastructure, and growing for export markets where commodity prices can fluctuate (Policy Working Group, 2011).

Some of these traditional supply cooperatives remain resilient nonetheless. Sussex, New Brunswick, is home to the world's oldest agricultural society, founded in 1841 (technically not a registered cooperative, according to the New Brunswick Financial and Consumer Services Commission), called Studholm Agriculture Society No. 21. Sussex farmers historically wanted to improve practices, cost-share, share breeding stock, etc. It is still primarily composed of farmers, but has a cooperative food store and other branches that have grown up over its history (Co-operative Enterprise Council of NB interview, 2011).

\section{Cooperative Grocery Stores in Decline}

The grocery cooperatives are facing real challenges. One participant put it like this:

\footnotetext{
Most cooperatives arise to address a need in difficult times such as the grocery cooperatives, which were formed because it was hard to get good quality groceries for an affordable price. The market has changed hugely. But you have to question now whether we need grocery cooperatives. (NB Foundation Session, 2008)
}

This trend is going on across the region. In the industrial town of Truro in central Nova Scotia, one of the authors, a cooperative member, saw first-hand the collapse of a grocery cooperative serviced by Co-op Atlantic. During the dissolution meeting a ruffled membership directed a lot of second-guessing at the directors, who in turn pointed to the membership voting with their dollars for "S\&S" (Sobeys \& Super-Store, the main retail grocery stores in Nova Scotia). This cooperative grocery store had more liabilities (CA $\$ 3.159$ million) than its CA $\$ 3.1$ million in assets (Truro Daily News, 2010). Some members hoped that local youth would carry forth the torch of cooperativization; others countered that youth do not even know what a cooperative is (Personal observation, December 17, 2009). The grocery cooperative's demise, which was followed by other highprofile closures of long-established family businesses in Truro, suggests a generalized hollowingout of once embedded community businesses (e.g., hardware, grocery, restaurants, furniture) by large corporate chains such as Walmart.

Overall, the supply cooperatives are resilient but being squeezed by large-scale consolidations upstream (suppliers) and downstream (retailers). Co-op Atlantic is still a big player in the region, but facing hurdles in part because many of its consumer cooperative members are struggling.

\section{Agricultural Service Cooperatives}

\section{Overview}

There has been a surge in service cooperatives capitalizing on the growing interest in local food, organic produce, fairly traded products, feed mills, specialty foods, sustainable products, foodprocessing incubators, small-scale food businesses, branding programs, delivery systems, innovative agricultural production, and new forms of agricultural marketing (CCA, 2011). Agricultural service cooperatives in Canada stand at 223 and include seed cleaning (84), farmers' markets (75), soil conservation (4), and other (60) (CCA, 2011). Nationally, 15 percent more cooperatives came into existence between 2007 and 2010 in areas such as livestock, vegetables, and fruit. Some of these "new" cooperatives are multistakeholder, involving both community members and producers (CCA, 2011).

Many informants expressed the belief that although the market for agriculture has changed dramatically, the future remains uncertain. Policymakers should therefore prioritize having a locally owned and democratically controlled food system:

For early adopters, those of us who are paying attention, there's awareness that those kinds of systems become unsustainable in a post-peak oil era. For the minority of people who think seriously about oil dependence, 
climate change, and fair trade, the trajectory that agriculture is on now isn't seen as a good thing to tie yourself to in the long run...Smaller organic and alternative cooperatives offer alternatives to the oildependent industrial model. The viability depends on how long farmers are able to hold out. (NS Foundation Session, 2008)

\section{Potential Growth Poles}

The service cooperatives are the main growth poles of the agricultural sector in Atlantic Canada. Informants were very optimistic about the thriving farmers' markets, part-time organic farms, as well as community-supported agriculture ventures. For example, there has been significant growth in farmers' markets throughout Nova Scotia — in Sydney, Lunenburg, Tatamagouche, Halifax, Wolfville, and Antigonish (Farmers Markets of Nova Scotia Co-operative n.d.) overseen by a second tier of cooperative and certification bodies like the Maritimes Certified Organic Growers Co-operative Ltd. Farmers' markets range from 12 vendors in a parking lot to the Seaport Market in Halifax, ${ }^{4}$ and have robust sales (NS Co-operative Council interview, 2013). One informant said: "Clearly the farmers' markets address the producer-consumer connections - restaurants and institutions as well." (Co-operative Enterprise Council of NB interview, 2011). Local sourcing in private and public institutions is seen as a way to capture additional market share for local food groups.

Off the coast of Newfoundland, Fogo Island residents set up a cooperative to put old farmland back into production and to store the crops with root cellars. Their harvest is fed back into restaurants and hotels. The members do not want to become too large or corporate:

Members of the cooperative are small-scale farmers on Fogo Island. So, with this cooperative they're building a tourism industry on local food marketing. This is an example of how different linkages between tourism and agriculture can create better

\footnotetext{
4 The Seaport Market went bankrupt in 2012 and was taken over by the Halifax Port Authority, a noncooperative.
}

opportunities for us to create small-scale, locally based opportunities (Nfld. \& Lab. Federation of Co-operatives interview, 2011).

This informant added that there is a need for government, including the Department of Agriculture, to look at Nfld. \& Lab. agriculture from the perspective of a small-scale production model populated by a new generation of farmer cooperators (age 20-30) imbued with a different kind of consciousness:

People used to think you needed 120 vegetable producers to form a cooperative, which is obviously a barrier in a province where there might not be 120 vegetable producers. A new, small organic cooperative leased a plot of land outside of St. John's [the capital of Nfld. \& Lab.]. They're all very smallproducing farmers, and they want it to be that way...It's a shift in thinking and a shift in views about whether or not you need to have a giant farm in order to contribute to the economy. (Nfld.\& Lab. Federation of Cooperatives interview, 2011)

This "new" cooperative consciousness can also be seen in similar community innovation in PEI with the growth of organic, and the regeneration of a 40-member vegetable growers cooperative, founded in 1971, that grades, packages, and markets root crops (PEI Co-operative Council interview, 2011). The fastest growing agricultural sector in New Brunswick is also organic, together with specialty crops (Co-operative Enterprise Council of NB interview, 2011). This reflects national trends, with organic farms growing from 1.5 percent of all farms in 2006 to 1.8 percent of all farms in 2012 (Statistics Canada, 2012c). Another informant said that when conventional farm revenue in the province is about 2 percent (and even below zero), value-adding and direct marketing can increase revenue to closer to 10 percent (NS Co-operative Council interview, 2011).

Informants did note, however, that organic has been damaged by cheaper imports of organic products. For example, customers at Co-op Atlantic outlets did not buy locally produced organic 
produce in the volume anticipated despite Co-op Atlantic's "Eat Atlantic Challenge" (NB Foundation Sessions, 2008). Interestingly, the PEI Council representative connected the traditional to new farmers (and potentially new cooperators) in the following way: "I know some of the farm stores in PEI that had been hard-core farm suppliers are trying to diversify and cater to smaller-scale hobby farmers and lifestyle farmers" (PEI Co-operative Council interview, 2011). The potential linkages between the traditional and new cooperatives are explored in the final section.

\section{Ad Hoc Government Support to Service Cooperatives} Informants said that the provincial and federal policy bias toward larger-size farms has been at the expense of support for the new service cooperatives. Potential initiatives mentioned as needing support included renewable energy, governmentlegislated community investment programs (some provincial support has been forthcoming here), mentorship programs (e.g., youth, second-career farmers, aboriginal peoples, new Canadians), intersectoral mentorship (e.g., fishing, forestry), the institutionalized purchasing of local food, and an enhanced role for cooperatives as suppliers, processors, and marketers (NS Co-operative Council interview, 2011; NS Department of Community Affairs, 2013; PEI Co-operative Council interview, 2011; personal communication from Rural and Cooperative Secretariat, 2010). Foundation Session participants more ambitiously called for the exploration of the role of the region's cooperatives in developing larger-scale projects and managing strategic clusters of assets (Policy Working Group, 2011). Farmers' organizations in the region could possibly help the agricultural cooperatives to leverage larger-scale projects.

\section{Relations with Farmers' Organizations}

Both the Canadian Federation of Agriculture and the National Farmers Union (NFU) have called for more resources to help farmers learn about, plan, and start agricultural cooperatives (CCA, 2011). The Co-operative Enterprise Council of New Brunswick did say that it frequently interacted with farmers' organizations through industry consultations, but that the council did not have any formal relationships with the farmers groups because they are neither council members nor cooperatives (Cooperative Enterprise Council of NB interview, 2011). It was acknowledged that more synergies could be built:

In a way, those organizations are subsets of the farms that are our members. The New Brunswick chair is a dairy farmer, for example. This council has a lot of involvement by Co-op Atlantic with overlapping membership. Many NFU members and dairy farmers are involved in cooperatives. There tends to be a natural overlap...I hadn't thought about working with them, but now that you mention it, they are our natural allies, and it would make sense. (Co-operative Enterprise Council of NB, 2011)

One stakeholder suggested farmers return to the cooperative practices of earlier generations:

We had those histories before in the different provinces. I mean I grew up on a farm myself and I just remember my grandparents and all of these people they all, all of their communities, had cooperatives...They had a threshing mill in common. They took turns, they could work out the days and the schedule and who could be there and the same when they bought a tractor together. (PEI Foundation Session, 2009)

Our research indicates that many farmers continue to see export platforms as the way to grow their businesses, which is not conducive to local level cooperation. The degree of unity within and between farmers' organizations on the accommodation of, or opposition to, the GF2 may shape the prospects for the region's agricultural cooperatives to build more locally grounded and sustainable rural cooperatives.

In general, the service cooperatives are community-driven with a new cooperative ethos, but require longer-term structural support by government in areas such as infrastructure, training, outreach, and broader policy shifts. 


\section{Agricultural Production Cooperatives}

\section{Overview}

Agricultural production cooperatives assist farmers in undertaking agricultural activities in the production process. Totalling 560, Canada's national breakdown is animal reproduction (12), grazing (162), feeder finance (234), farm (34), machinery (77), tree farming (17), and other (24) (CCA, 2011). Production cooperatives were only infrequently brought up by our informants, although two examples of equipment-sharing cooperatives in Nova Scotia were mentioned: a successful one in Inverness County, and a less successful one in the Annapolis Valley (NS Farm Board representative interview, May 2011). Regionally, production cooperatives are primarily common pasture holdings.

\section{Community Land Trusts and Farming Cooperatives}

Farming cooperatives, however, were mentioned in relation to the establishing of community land trusts for the protection of farmland (Co-operative Enterprise Council of NB interview, 2011; PEI Foundation Session, 2009; NS Foundation Session, 2008). One informant put the question of farmland use this way:

One of the key issues is the local ownership and governance that typify cooperatives. The federal government tends to emphasize competition and innovation. There's very little in agricultural policy, either federally or provincially, around food security, and very little attention paid to who owns the land or where the profits end up. I think cooperatives are part of the spectrum of solutions that you need in order to respond to food security concerns, and in order to ensure the resilience of the agricultural sector in the rural communities that it thrives in. (Cooperative Enterprise Council of NB, 2011)

A key component of community landownership is the community land trust (CLT) model. CLTs are private charitable organizations whose primary purpose is the preservation of land under stewardship agreement, covenants, and other restrictive legal tools (Reakes, 2007). CLTs are democratically run, with open membership, which potentially allows residents of the local community in which they are located to participate in its governance and carry out external oversight. A combined land trust/farming cooperative would not only keep land affordable and under community control, but also pool resources, machinery, marketing, and labor where a prospective CLT's land could be farmed either communally or be divided into individual members' plots. This would give alternative farmers a greater voice politically. ${ }^{5}$ One stakeholder opined that cooperative landownership gives local people a shot at purchasing farmland from farmers rather than developers (NS Foundation Session, 2008). In Nova Scotia, CLTs typically have the goal of wilderness conservation. However, one agriculturally oriented CLT in Tatamagouche, Nova Scotia, has the aim of stewarding 60 acres (24 ha) of agricultural land and 40 acres (16 ha) of woodland (Hanavan, 2011).

Other Land Tenure Models for Farming Cooperatives The Co-operative Enterprise Council of New Brunswick representative said, "I'm not aware of any land cooperatives in New Brunswick that currently exist, but there are a number of groups that we're assisting that are interested in cooperatively owning land or leasing crown land" (Cooperative Enterprise Council of NB interview, 2011). One cooperative activist suggested that farming cooperatives are marginal because their revenue margins are very low, the work is very labor-intensive, and they offer little in the way of employment and pension benefits (Rural and Cooperative Secretariat, personal communication, 2010). In fact, the only concrete case of a largefarming cooperative cited, Ocean Spray, a traditional agricultural cooperative of growers of cranberries and grapefruit headquartered in Massachusetts, leased 850 acres ( $344 \mathrm{ha}$ ) of provincial crown land at nominal rates for 90 years near Rogersville, New Brunswick, on cranberry-producing bog and wetlands (Co-operative Enterprise Council of NB interview, 2011).

To address the decline of local food produc-

\footnotetext{
${ }^{5}$ Case studies of a few agricultural land trusts in the U.S. are provided in Preservation of Agricultural Land in Nova Scotia (NS Agricultural Land Review Committee, 2010).
} 
tion as well as the obstacles facing the possibilities inherent in large-scale farm cooperatives, a member of the Nova Scotia Co-operative Council is beginning to develop an innovative business concept based on a 100-member cooperative mixed farm (vegetables, livestock, blueberries etc.) with a land base of 10,000 acres (4,047 ha) called Fundy Farms. The business concept also envisions having centralized services (e.g., accounting, marketing) as well as pensions and benefits to stabilize the membership with long-term security. Although there were numerous dimensions to the business plan, a key question in the context of the proposed business is whether farm real estate markets could even support such a large-scale farm cooperative. This question led the authors to interview two government representatives specializing in farmland real estate markets. Our informants said that blocks of land frequently come up for sale in parcels of 2-3 acres (0.8-1.2 ha), 30 acres (12 ha), etc., but larger parcels are uncommon:

[Ten thousand] acres of woodland is possible, but it's hard to think of being able to get 10,000 acres of agricultural land. Some families have been building up land bases for six generations and haven't been able to achieve that. (NS Farm Board interview, 2011)

An incremental approach was deemed more feasible, whether through membership, equipment purchases, projects, or land base, and slowly growing through its successes (Farm Credit Canada representative, 2011; NS Farm Board representative, 2011).

Despite some initiatives among progressive circles, the production cooperatives remain peripheral and would require a sea change in public policy, or some kind of natural or human caused "shock" to the global economy, to take root.

Below we situate the discussion within the two broad objectives of this paper.

\section{Toward A New Form of Rural Cooperation}

Impact of Agricultural Cooperatives on Domestic Food Production

The reader is reminded that the first objective of the paper was to evaluate whether agricultural cooperatives could revive domestic food production at the local and regional levels. The interviews elicited the hard choice facing agricultural cooperatives between working within the GF2 frame, or going beyond it to carve out new kinds of domestic markets. The interviews revealed that despite the notable successes in developing niche markets and spawning innovation, the region's agricultural cooperatives would be fortunate to hold onto their current overall market share of domestic food production. While the government-supported marketing cooperatives are the most economically secure, the service cooperatives are the most dynamic and community-driven. What all subsectors share in common, nonetheless, is an emerging globalized policy context that will further loosen the presence of government and community in the region's agricultural economy.

The general policy pattern vis-à-vis agricultural cooperatives suggests the following: the traditional cooperatives (marketing, supply) are lodged between the decline of the Keynesian-era (state supported) agricultural model and the current "getbig-or-get-out" neoliberal model, and are being incrementally disembedded from current agricultural policy. The newer service cooperatives remain largely unembedded in any agricultural policy framework whatsoever. The cooperative community in Atlantic Canada has registered some successes, but in general is not preparing itself for the dramatic changes coming its way. Federal and provincial policies will only compound the challenges facing agricultural cooperatives and continue the trends toward conventionalization and dissolution, and loss of focus on the social justice and community economic development that are essential components of rural cooperation.

John Jacobs (2006) critically notes that the SM marketing cooperatives have become too corporate and have lessened their progressive community roots to the point of being virtually indistinguishable from private companies. This begs the question as to whether the traditional cooperatives hold any future relevance for reviving the regional and local cooperative infrastructure. What is clear is that the SM marketing cooperatives still remain more democratic and community-centered than conventional 
investor-owned businesses; their disappearance would accelerate family farm decline. The supply cooperatives, moreover, could still play a critical role in the distribution of affordable inputs to the new cooperatives. At the same time, the new service cooperatives remain small in number, and more evidence of their impact on local food production is required. Likewise, the farming production cooperatives lack a "champion" in government, the farming sector, or the cooperative sector, which does not bode well for their future given the high degree of cohesion and commitment whether religious, political, or social — required to make them work (Helm, 1968). Detailed business plans on scaling up farming cooperatives would also be requisite, requiring comparison pricing between foreign and domestic foodstuffs. All segments remain vulnerable to the vicissitudes of the world economy.

The second objective was to identify the political and economic challenges and opportunities for the success of local-scale agricultural cooperatives in Atlantic Canada. Below we identify these challenges and opportunities on two levels: first, those stemming from the two solitudes existing between the traditional and new cooperatives; and second, the interprovincial silos among the cooperative councils themselves.

\section{The Relationship Between the Traditional and New Agricultural Cooperatives}

What stood out from the interviews was how infrequently the traditional and new agricultural cooperatives in Atlantic Canada were interrelated. This perhaps confirms Vieta's (2010) observation of there being two co-existing cooperative solitudes: the ethos of a "new cooperativism" defined by food as a right; ecological sensitivity; redefined human/farm animal relationships; smallscale production for local markets; low-input agriculture; nontraditional gender roles in farming; and so forth — that largely bypasses the commodity orientation of the traditional, better-off marketing cooperatives wedded to the status quo. The challenge of bringing such a heterogeneous and yet vulnerable sector together is truly daunting. How can the disparate collection of agricultural cooperatives effect a more unified model that links its marketing, supply, services, and production sections?

One step toward a fusion of the traditional and new segments would be to transition to a more domestically oriented decommoditized agricultural value chain. Helpful here in rethinking such a transition is to bring into relationship the advantages of the "cooperative effect" (the pooling of individual resources) - including handling of large volumes of products, reducing the costs of inputs, doing value-added processing, using common grading systems, strengthening market position, increasing technical specialization, reducing exposure to risk, obtaining needed products and services, and pooling land and capital for investment - with a "multifunctional" paradigm where Canadian agriculture's environmental and social roles are prioritized, instead of just the traditional commodity focus on "food, fuel and fiber" (CCA, 2011; Helm, 1968; Senate Committee, 2008). While the Senate Report does not detail the role of cooperatives, it does set an alterative agenda for new ways to structure the provision of agricultural goods and services. The possibilities for a renewed rural cooperative architecture are not difficult to imagine.

How can the conventional infrastructure of yesteryear be adapted to a rural cooperative policy that strengthens all segments of the agricultural cooperatives? Innumerable permutations are possible. Desmarais and Wittman (2014) suggest that the SM quota revert back to a marketing agency for affordable reallocation to new entrants when the original quota-holding producer leaves the industry, rather than being privately traded as at present. To take another example, non-SM marketing cooperatives could undertake value-added activities related to grains, vegetables, fruits, organic produce, and locally raised livestock, backed by common grading systems. So-called "lifestyle" farms could join supply cooperatives and purchase regionally produced, scale-appropriate inputs in niche industries such as breweries, wineries, and exotic animal wool. "New" non-SM marketing cooperatives could reduce transaction costs for community supported agriculture (CSA) groups through joint marketing. In the production sub sector, the pooling of capital and land for investment could be undertaken on a cooperative basis, 
whether through machine sharing by conventional farmers, CLT formation by emergent farmers, or organic pasture initiatives by livestock farmers. Cooperatives could also be formed for wetland production and rural heritage (Senate Committee, 2008). Another issue raised in the research was intersector linkages (e.g., sustainable fisheries and forestry). Here, the formation of multipurpose/ multistakeholder rural cooperatives could potentially tap these synergies and others, while simultaneously strengthening the rural communities in which they are embedded.

\section{Scaling up the Interprovincial Cooperative Councils}

Our interviews further revealed that there is little in the way of alliance-building across the provincial jurisdictions. Our informants were certainly aware of the problem as indicated by the importance they placed on learning from, and networking with, other cutting-edge regions in Canada, especially Quebec (PEI Co-operative Council interview, 2011; CCA, 2011). But by all appearances, the councils do not see a strategy for turning things around in a collaborative manner that could capture lucrative decommoditized supply value chains. They need to adopt a more proactive strategy that disengages agricultural cooperatives from the current unstable status quo and instead reconnect to regional partners while striving for fairer trade relationships and networks internationally around key commodities. To simply compete to be the low-price leader in the contemporary global economy has become an unwinnable race to the bottom. What is really needed is a wholesale re-envisioning and restructuring of the current disparate collection of cooperatives into, say, a unified tertiary agricultural cooperative federation for Atlantic Canada (and eventually, nationally) that links marketing, supply, services, and production in a more localized and integrated value chain in which all see the benefit of nurturing its weakest parts. ${ }^{6}$

Such an entity could strengthen the membership profile of the councils by offering centralized services, including technical business specialization

${ }^{6}$ Once again, Quebec is the leader, having the closest to an apex organization of agricultural cooperatives in Canada, known as Co-op Fédérée (CCA, 2011, p. 5). (brought up in the Fundy Farms concept), trainingof-trainers for community mobilization, IT services for brand promotion marketing, and a government- and industry-funded "co-op to co-op" extension system geared to community outreach and relocalization initiatives. Further, a tertiary entity supported by, or of, the Atlantic Canadian councils could lobby governments to reconsider the "one size fits all" approach to regulation raised repeatedly in the research process. This administrative hurdle (e.g., the provincial health and safety guidelines that hamstring cooperatives from more streamlined interprovincial trade) impacts the ability of cooperatives to ground value-added agriculture regionally.

\section{Conclusion}

This strategic policy analysis looked at what new role agricultural cooperatives might play in a more regionalized marketplace in Atlantic Canada. Using a mixed-methods approach we gathered secondary data and interviewed key leaders and managers in the agricultural cooperative community in Atlantic Canada. Results suggested that while progress is being made to decommodify and develop new value-added products and regionally oriented supply chains, a transition to a more sustainable regional economic cooperative model is not likely to come about without a more localized rural cooperative system uniting all agricultural cooperatives, and a greater unity between the provincial cooperative councils.

Looking to the medium term, a national food strategy with a cooperative lens, alluded to by several informants, could address the challenges facing the region's farmers and could achieve the elusive unity between agricultural cooperatives and farmers' organizations based on the shared goal of reversing the decline in regional food production. Atlantic Canada's smaller scale conventional family farms, and the not insignificant lifestyle farms, are less pathway-dependent on GF2 strategies than the larger more monocultural farms found in other regions of Canada, and could more easily transition into an alternative rural paradigm.

\footnotetext{
${ }^{7}$ Of Canada's 10 provinces, only Nova Scotia saw a growth in census farms. The growth was 2.9 percent between 2006 and
} 
We have also seen the critical role government policy plays in both creating and breaking up domestic markets. A coalition of cooperatives and farmers' organizations, together with other organizations, could pressure federal and provincial governments to adapt a rural multifunctional strategy by lobbying for and demanding reforms in spheres such as enhancement of Supply Management, targeted and well-funded programs to new entrants, carbon pricing, and a critical policy review of the plethora of free-trade agreements wreaking havoc in rural communities. These and other reforms could see the agricultural cooperatives play their part in the broader transition called for at the Quebec summit.

\section{Acknowledgements}

The authors wish to thank the Social Sciences and Humanities Research Council of Canada, the Rural Research Centre of the Faculty of Agriculture of Dalhousie University, the Atlantic Co-operative Councils, and other informants, for their support and cooperation, which has made this research possible. Professor Leslie Brown of Mount Saint Vincent University read an earlier draft and provided extremely insightful comments. We are also grateful to the three blind peer reviewers for their extensive feedback. The JAFSCD staff's inputs in the final stages of the paper were invaluable in sharpening its focus. The authors alone remain responsible for any shortcomings in this paper.

\section{References}

Agriculture and Agri-Food Canada. (n.d.). Growing Forward 2. Retrieved October 2013, from http://www.agr.gc.ca/eng/about-us/keydepartmental-initiatives/growing-forward2/?id=1294780620963

Brown, L. (1995). Co-op Atlantic. In International Joint Project on Co-operative Democracy Centre for the Study of Co-operatives (Ed.), Making membership meaningful: Participatory democracy in co-operatives (pp. 149-179). Saskatoon, Canada: University of Saskatchewan.

2011 (3,905 farms), mainly of smaller farms (Statistics Canada, 2012).

Advance online publication
Canadian Co-operative Association (CCA). (2011). Growing forward through co-operation: Co-operatives and the next agricultural policy framework for Canada. Retrieved from http://www.coopscanada.coop/en/gov affair/Sub missions to Government

Canadian Geographic. (n.d.). Atlantic Region. Retrieved from http://www.canadiangeographic.ca/atlas/ themes.aspx?id $=$ atlantic\&sub $=$ atlantic industry $\underline{\text { farms }}$

Canadian Worker Co-op Federation. (n.d.). Coopzone News. Federal government cuts Co-operative Development Initiative. Retrieved September 2013 from http://www.canadianworker.coop/news/ general-news/federal-government-cuts-cooperative-development-initiative

Dairy Commission of Canada. (2012). Supply management. Retrieved October 2013 from http://www.cdcccl.gc.ca/CDC/index-eng.php?link=114

Desmarais, A., \& Wittman, H. (2014). Farmers, foodies and First Nations: Getting to food sovereignty in Canada. Journal of Peasant Studies. Advance online publication. http://dx.doi.org/10.1080/03066150.2013.876623

Farmers' Markets of Nova Scotia. (n.d.). Nova Scotia Farmers' Markets. Retrieved May 2014 from http:/ / farmersmarketsnovascotia.ca/

Forsythe, T. K. (2011). Lamb marketing co-operative to celebrate 30 years. Atlantic Co-operator, 77(5). Retrieved from http://www.theatlanticcooperator.coop/theatlanticcooperator/PostDetailS/ tabid/69/language/en-US/Default.aspx?id=160

Fredericton Daily Gleaner. (2005, June 10). Business community welcomes Atlantica concept. Retrieved from http://www.aims.ca/en/home/library/ details.aspx $/ 1158$

Hanavan, L. (2011). Report to Nova Scotia Co-operative Council. On file with author.

Helm, F. C. (1968). The economics of co-operative enterprise. Moshi, Tanzania: Co-operative College.

Industry Canada. (2013). Incorporating your cooperative. Retrieved from http://www.ic.gc.ca/eic/site/ cd-dgc.nsf/eng/cs03954.html

International Co-operative Alliance [ICA]. (n.d.). Co-operative facts \& figures. Retrieved October 2013 from http://ica.coop/en/whats-co-op/ cooperative-facts-figures 
Jacobs, J. (2006, October 3). Corporate-think co-opting coops? [Commentary]. Canadian Centre for Policy Alternatives. Retrieved from http://www.policyalternatives.ca/publications/ commentary/corporate-think-co-opting-co-ops

Johnson, D., Hodgett, S., \& Royle, S. A. (2007). Regional development and the development of theory. In S. Hodgett, D. Johnson, \& S. A. Royle (Eds.), Doing development differently: Regional development on the Atlantic periphery (pp. 17-41). Sydney, Nova Scotia: Cape Breton University Press.

MacPherson, I. (1979). Each for all: $A$ bistory of the cooperative movement in English Canada, 1900-1945. Toronto: Macmillan of Canada.

McKenna, B., \& Curry, B. (2012, June 21). Pacific free traders eye Canada's dairy, poultry markets. Globe and Mail. Retrieved From http://theglobeandmail. com/news/politics/pacific-free-traders-eyecanadas-dairy-poultry-markets/article4358953

Nova Scotia Agricultural Land Review Committee. (2010). Preservation of agricultural land in Nova Scotia. Halifax, Nova Scotia: Author. Retrieved from http://www.novascotia.ca/agri/elibrary/nsalrc/ NSALRC-Final $\% 20$ Report-Discussion.pdf

Nova Scotia Co-operative Council. (n.d.). [Membership listing.] Retrieved October 2013 from http://www.novascotia.coop/our-co-ops/ member-directory [no longer online]

Nova Scotia Department of Community Affairs. (2013). Community Economic Development Investment Funds.

Retrieved from http://www.novascotia.ca/econ/cedif/

Nova Scotia Federation of Agriculture. (n.d.). Reduced food miles brings benefits. Retrieved October 2013 from http://nsfa-fane.ca/programs-projects/food-milesproject/

Novkovic, S. (2012, October). Key take home messages. Presentation at the Imagine 2012 Conference on Co-operative Economics and the International Summit of Co-operatives in Quebec City. Webinar retrieved from http://www.cooperativedifference. coop/en/hub/Events-Opportunities\#Imagine

Policy Working Group. (2011, March). The Wilds, Salmonier Line, Nenfoundland, Summary. On file with author.

Powell, M. (2011, December 15). It's beginning to look a lot like Christmas... in Dubai? Retrieved from the
Canadian Manufacturing website:

http://www.canadianmanufacturing.com

Reakes, V. (2007). Establishing your community farm trust:

Legal tools and comparative models [Draft]. Victoria,

British Columbia: Environmental Law Centre.

Retrieved from http://www.elc.uvic.ca/ documents/ELC-Community-Farm-TrustHandbook.pdf

Scott, J., \& Colman, R. (2008). Towards a healthy farm and food system: Indicators of genuine progress. Retrieved from the Organic Agriculture Centre of Canada website: http://www.organicagcentre.ca/Docs/GPI $\% 20$ Atlantic/Healthy Farm 09 opt.pdf

Senate Committee on Agriculture and Forestry. (2006). Understanding freefall: The challenge of the rural poor [Interim report]. Retrieved from http://www.parl.gc.ca/Content/SEN/Committee/ 391/agri/rep/repintdec06-e.pdf

Senate Committee on Agriculture and Forestry. (2008). Beyond freefall: Halting rural poverty [Final report].

Retrieved from

http://www.parl.gc.ca/content/sen/committee/39 2/agri/rep/rep09jun08-e.pdf

Statistics Canada. (2012a). Canada's rural population since 1851. Retrieved October 2013 from http://www12.statcan.gc.ca/census-recensement/ 2011/as-sa/98-310-x/98-310-x2011003 2-eng.cfm

Statistics Canada. (2012b).Chapter 1. Retrieved October 2013 from http://www.statcan.gc.ca/pub/95-640x/2012002/01-eng.htm

Statistics Canada. (2012c). Chapter 5. Retrieved October 2013, from http://www.statcan.gc.ca/pub/95-640x/2012002/05-eng.htm

Truro Daily News. (2010, April 20). Co-op deal in final stage. Retrieved from http://www.trurodaily.com/News/Local/2010-0420/article-1031399/Co-op-deal-in-final-stage/1

United Nations Department of Economic and Social Affairs. (2013). World Economic Situation and Prospects. December. Retrieved from http://www.un.org/en/development/desa/policy/ wesp/wesp2013/wesp13update.pdf

Vieta, M. (2010). The New Cooperativism. (Editorial), Affinities: A Journal of Radical Theory, Culture, and Action. Volume 4, Number 1. Retrieved from http://affinitiesjournal.org/index.php/affinities/ article/view/47/147 


\section{Appendix}

\section{Sample Semistructured Interview Guide}

- How long has your cooperative/council been in operation? What were the motivations in its formation? How has it changed since its inception?

- What are the goals of your cooperative/organization?

- To what extent has the cooperative/organization succeeded in achieving its goals? Where has it encountered challenges?

- Do you see your cooperative/organization playing a role in changing agriculture? (Production models? includes Fundy case study; New entrants? Land availability? Buy-local?)

- Has your cooperative had any relationship with industry organizations (or vice versa) in your province (e.g., NSFA, NFU in NB and PEI)? If so, what have been the benefits and challenges of these relationships? Have you engaged in joint projects? If so, please give examples.

- What motivates people to participate in your cooperative/organization? What might deter people from participating? (Benefits? Drawbacks? Costs of involvement? Networking? Services provided?)

- Have you been able to engage the public in understanding the cooperative model? If so, how? What is the importance of this engagement? Do you have a strategy for monitoring public engagement? Which techniques have been most effective? Least effective?

- Has government policy had an impact on the success of your cooperative/organization? If so, how? (Benefits? Challenges? Which policies?)

- Anything you'd like to add? 